\title{
Waiting: Cultural Techniques, Media, and Infrastructures
}

In discussions on cultural techniques and in reflections on infrastructures, we come across the fact that both concepts are described by reference to materiality, interconnectedness, and processuality. However, research into cultural techniques and the field of infrastructure studies do not explicitly refer to each other. Taking this diagnosis as a starting point, the following paper explores the connection between cultural techniques and infrastructures. Such an approach is guided by the assumption that it can be productive to confront research on cultural techniques with insights from infrastructure studies, in order to elaborate on the socio-technical-discursive dimension of cultural techniques and infrastructures, respectively. Especially with regard to the notion of media, infrastructure studies could benefit from integrating a perspective on cultural techniques, just as research into cultural techniques may gain insights by taking up arguments from infrastructure studies. And even beyond that: media theory can be seen as the field where cultural techniques and infrastructures have a common ground.

The argument will unfold in four steps. In the first part, I will briefly sketch differences as well as proximities between research into cultural techniques and studies of infrastructures. In the second part, I will concentrate on the cultural technique of waiting to elaborate on its entanglement with infrastructural settings. In the third part, I will illustrate this idea by focusing on historical reflections on the upkeep of steam engines and railway maintenance in the nineteenth century. In the fourth part, I will briefly summarize important aspects and provide further perspectives.

\section{Cultural Techniques and Infrastructures}

Research into cultural techniques as well as infrastructure studies represent comparably young research agendas. The cultural-techniques approach originates from what has been labeled "German media theory." 1 With respect to media

1 See Geoffrey Winthrop-Young, "Cultural Studies and German Media Theory," in New Cultural Studies: Adventures in Theory, ed. Gary Hall and Clare Birchall (Edinburgh: Edinburgh University Press, 2006), 88-104; Eva Horn, “Editor's Introduction: 'There Are No Media," Grey Room 29 (2008): 6-13. 
and communication studies in North America, German media theory was on a "collision course," as it abandoned "mass media and the history of communication in favor of those insignificant, unprepossessing technologies that underlie the constitution of meaning."2 After its "antihermeneutic" phase from the early 1980s to the late 1990s, and in its "posthermeneutic" phase from the late 1990s to the present, media theory conceptualized media as cultural techniques. ${ }^{3}$ In contrast to posthumanist thought in North America, which tends toward biological concepts and, therefore, toward focusing on the relation between humans and animals, the "nonhuman" stance of the German cultural-techniques approach always relates to techniques, technologies, and machines. ${ }^{4}$ Thus, the concept of Technik is core: "Its semantic amplitude ranges from gadgets, artifacts, and infrastructures all the way to skills, routines, and procedures." ${ }^{5}$ Understood in this way, the notion of Technik already provides a link between the dimension of practice and know-how on the one hand, and of stabilized material formations on the other. The field of infrastructure studies took up ideas from science and technology studies, from the large technical systems approach, from Actor-NetworkTheory, and from practice theory in order to discuss, in particular, the challenges brought about by information infrastructures since the late $1980 \mathrm{~s}^{6}{ }^{\text {The insights }}$ of infrastructure studies concerning information, energy, or transport infrastructures have been addressed with respect to their potential for media theory. ${ }^{7}$

2 Bernhard Siegert, Cultural Techniques: Grids, Filters, Doors, and Other Articulations of the Real (New York: Fordham University Press, 2015), 3.

3 Siegert, Cultural Techniques, 6.

4 See Siegert, Cultural Techniques, 8. For an introduction to cultural techniques for an AngloAmerican audience, see also Geoffrey Winthrop-Young, "Cultural Techniques: Preliminary Remarks," Theory, Culture \& Society 30, 6 (2013): 3-19.

5 Geoffrey Winthrop-Young, “Translator’s Note,” in Siegert, Cultural Techniques, xv.

6 See Susan L. Star and Karen Ruhleder, "Steps Toward an Ecology of Infrastructure: Design and Access to Large Information Spaces," Information Systems Research 7, 1 (1996): 111-134; Paul N. Edwards et al., Understanding Infrastructures: Dynamics, Tensions, Designs: Report of a Workshop on 'History \& Theory of Infrastructure: Lessons for New Scientific Cyberinfrastructures' January 2007, https://deepblue.lib.umich.edu/bitstream/handle/2027.42/49353/UnderstandingInfrastructure2007. pdf (visited on July 17, 2019); Geoffrey Bowker et al., "Toward Information Infrastructure Studies: Ways of Knowing in a Networked Environment," in International Handbook of Internet Research, ed. Jeremy Hunsinger et al. (Dordrecht and London: Springer, 2010), 97-117.

7 See Gabriele Schabacher, "Mobilizing Transport: Media, Actor-Worlds, and Infrastructures," Transfers 3, 1 (2013): 75-95; Gabriele Schabacher, "Time and Technology: The Temporalities of Care," in Hardwired Temporalities: Media, Infrastructures, and the Patterning of Time, ed. Axel Volmar and Kyle Stine (Amsterdam: Amsterdam University Press, forthcoming). On the relevance of Actor-Network-Theory for media theory see Tristan Thielmann and Erhard Schüttpelz (eds.), Akteur-Medien-Theorie (Bielefeld: transcript, 2013); for respective reflections on the work 
However, to mention cultural techniques and infrastructures in one breath is by no means a matter of course. At first glance, differences are notable. Infrastructures and cultural techniques seem to be located at opposite ends of the structure-agency relation. Thus, cultural techniques seem to refer to practices, infrastructures to materialities. Second, cultural techniques seem to articulate a premodern, even nonmodern, bias, while infrastructures, at least in the narrower sense, clearly seem to belong to the realm of modernity and only emerge in the horizon of industrialization during the nineteenth century. Third, cultural techniques appear to relate to (sequential) operations, while infrastructures seem to refer to (standardized) systems. Taking this into account, the question arises why it might make sense to relate the two concepts to each other. My argument is that both approaches are based on similar intuitions.

The first intuition concerns the fact that research into cultural techniques as well as infrastructure studies criticize the idea of hylemorphism, according to which subjects appear to be actors that intentionally shape the "material" of the cultural field. ${ }^{8}$ This idea is opposed to the notion of "heterogeneous engineering" ${ }^{9}$ by different actors that form socio-technical-discursive embroglios. Both perspectives are thus based on the idea of a fundamental interconnectedness of the actors involved (be they stones, people, or regulations). Research into cultural techniques, however, primarily has actor-networks and their trajectories in the sense of ANT in mind; it underlines the priority of the chaine opératoire over the resulting artefacts and concepts. ${ }^{10}$ In the heuristic sense, this priority means that "the task of an archeological reconstruction of technical operative chains ... is prior to all the involved, all reconstructed, found, documented, explored entities."11

of Susan L. Star, see Sebastian Gießmann and Nadine Taha (eds.), Susan Leigh Star: Grenzarbeit und Medienforschung (Bielefeld: transcript 2017).

8 For the critique of the hylemorphistic model and the idea of a different understanding of materiality, see Tim Ingold, “Toward an ecology of materials," Annual Review of Anthropology 41 (2012): 427-442.

9 John Law, "Technology and Heterogeneous Engineering: The Case of the Portuguese Expansion," in The Social Construction of Technical Systems: New Directions in the Sociology and History of Technology, ed. Wiebe E. Bijker, Thomas P Hughes, and Trevor Pinch (Cambridge, MA: MIT Press, 1987), 111-134.

10 Taking recourse to André Leroi-Gourhan, as well as to Marcel Mauss and Antoine Hennion, Erhard Schüttpelz reconstructs the relevance of these "operational chains" for the analysis of media; see Erhard Schüttpelz, "Die medienanthropologische Kehre der Kulturtechniken," Archiv für Mediengeschichte 6 (2006): 87-110, here 91ff.; E.S., "Die Erfindung der Twelve-Inch der Homo Sapiens und Till Heilmanns Kommentar zur Priorität der Operationskette," Internationales Jahrbuch für Medienphilosophie 3, 1 (2017): 165-182.

11 Schüttpelz, "Die Erfindung," 166; my translation. 
Thomas Widlok's analysis of cracking Mangetti nuts in northern Namibia would be an example of such a chaine opératoire ${ }^{12}$ Infrastructure research, on the other hand, understands the idea of interconnectedness more strongly as a type of (historical) layering, which is expressed in the concept of the path dependency of large technical systems. ${ }^{13}$ Edwin Hutchins' analysis of distributed cognition in ship navigation can be understood as drawing together these two perspectives. Hutchins shows how the order of the steps in which something has to be done, the organization of the career cycle of navigation practitioners, and the spatial setting on board large ships are interrelated. ${ }^{14}$ This example illustrates an aspect that is repeatedly emphasized in Susan Leigh Star's reflections on infrastructures: large-scale technical systems exist only in concrete constellations of use ("communities of practice" ${ }^{15}$ ) that determine how systems perform. Cultural techniques and infrastructures are thus both characterized by networked structuring, be it sequential chains of operations and "meshworks"16 in the case of cultural techniques, or systems of different "communities of practice" based on distributed and standardized procedures in the case of infrastructures.

A second intuition that both research perspectives share concerns a strong interest in the invisible and implicit operations that work on a preconceptual, habitual, or indirect level to guarantee the functioning of things. Thus, cultural

12 Thomas Widlok, "Kulturtechniken: ethnographisch fremd und anthropologisch fremd: Eine Kritik an ökologisch-phänomenologischen und kognitiv-modularisierenden Ansätzen," in Fremdheit Perspektiven auf das Andere, ed. Thomas A. Kienlin (Bonn: Rudolf Habelt, 2015), 41-59, here 45ff. Widlok also analyzes the "effective chain" to produce an arrow (Widlok, "Kulturtechniken," 53) within the process of hunting with bow and arrow as a whole as depicted by Marlize Lombard and Miriam Noël Haidle, “Thinking a Bow-and-Arrow Set: Cognitive Implications of Middle Stone Age Bow and Stone-Tipped Arrow Technology," Cambridge Archaeological Journal 22, 2 (2012): 237-264. 13 See Edwards et al., Understanding Infrastructures, 17ff.; Lawrence Busch, Standards: Recipes for Reality (Cambridge, MA, and London: MIT Press, 2011); for the concept of momentum, see Thomas P. Hughes, "The Evolution of Large Technological Systems," in The Social Construction of Technological Systems, ed. Wiebe E. Bijker, T.P.H., and Trevor Pinch (Cambridge, MA: MIT Press, 1989), 51-82, here 76ff.; on the "lock-in" effect of standards, see also Monika Dommann, “08/15, Querty, PAL-SECAM, Paletten und MP3: Standards als kulturelle Artefakte,” in Geltung und Faktizität von Standards, ed. Thomas M. J. Möllers (Baden-Baden: Nomos, 2009), 253-260.

14 Edwin Hutchins, “The Technology of Team Navigation," in Intellectual Teamwork: Social and Technological Foundations of Cooperative Work, ed. Jolene Gallegher et al. (New York/London: Psychology Press, 1990), 191-220.

15 See Jean Lave and Étienne Wenger, Situated Learning: Legitimate Peripheral Participation (Cambridge: Cambridge University Press, 1991); Geoffrey C. Bowker and Susan L. Star, Sorting Things Out: Classification and Its Consequences (Cambridge, MA, and London: MIT Press, 1999), here $293 \mathrm{ff}$.

16 Tim Ingold, Lines: A Brief History (London: Routledge, 2007), 80. 
techniques research focuses on the preconceptual status of practices ("cultural techniques - such as writing, reading, painting, counting, making music - are always older than the concepts that are generated from them," ${ }^{17}$ such as "number" or "image"), on their embeddedness in architectural environments (one thinks of the operativity of architectural elements such as gate or door, wall, and corridor), ${ }^{18}$ as well as on the appreciation of supposedly inferior cultural techniques (such as repairing). ${ }^{19}$ This perspective on cultural techniques can be linked to the research on "invisible work," 20 on "tacit knowledge," ${ }^{21}$ and on habitual routines $^{22}$ in the context of infrastructure analyses. For both approaches, the specific efficacy of practices is key, especially because they become visible only when networks fail. For this reason, moments of disruption (malfunction, accident, disaster) are highly relevant as knowledge-generating instances. ${ }^{23}$

17 See Thomas Macho, “Zeit und Zahl: Kalender und Zeitrechnung als Kulturtechniken,” in Bild Schrift - Zahl, ed. Sybille Krämer and Horst Bredekamp (Munich: Fink 2003), 179-192, here 179.

18 See Bernhard Siegert, "Door Logic, or, the Materiality of the Symbolic: From Cultural Techniques to Cybernetic Machines," in B.S., Cultural Techniques, 192-205; Stefan Trüby, Geschichte des Korridors (Paderborn: Fink, 2018); Markus Krajewski, The Server: A Media History from the Present to the Baroque (New Haven and London: Yale University Press, 2018), Chapter 1.

19 See Gabriele Schabacher, "Im Zwischenraum der Lösungen: Reparaturarbeit und workarounds," ilinx 4 (2017): XIII-XXVIII. For studies on repair from different disciplinary backgrounds, see Kulturen des Reparierens: Dinge - Wissen - Praktiken, ed. Stefan Krebs, Gabriele Schabacher, and Heike Weber (Bielefeld: transcript, 2018); Stephen Graham and Nigel Thrift: "Out of Order: Understanding Repair and Maintenance," Theory, Culture \& Society 24, 3 (2007): 1-25; Reinhold Reith and Georg Stöger, "Einleitung: Reparieren - oder die Lebensdauer der Gebrauchsgüter," Technikgeschichte 79, 3 (2012): 173-184; Steven J. Jackson, “Rethinking Repair," in: Media Technologies: Essays on Communication, Materiality, and Society, ed. Tarleton Gillespie, Pablo J. Boczkowski, and Kirsten A. Foot (Cambridge, MA, and London: MIT Press, 2014), 221-239. 20 Susan Leigh Star and Anselm Strauss, "Layers of Silence, Arenas of Voice: The Ecology of Visible and Invisible Work," Computer Supported Cooperative Work 8 (1999): 9-30.

21 Michael Polanyi, The Tacit Dimension (New York: Doubleday Company, 1966).

22 Bowker and Star, for example, turn the attention to Sacks' "doing 'being ordinary"' (Harvey Sacks, Lectures on Conservation, vol. 2 [Oxford: Blackwell, 1992], 216) as a form of "naturalization" and "familiarity" in everyday work practice that desituates objects to the status of transparency (Bowker and Star, Sorting Things out, 299). With respect to work practice and information technologies, see also Paul Luff, Jon Hindmarsh, and Christian Heath (eds.), Workplace Studies: Recovering Work Practice and Informing System Design (Cambridge: Cambridge University Press, 2000).

23 See Christian Kassung (ed.), Die Unordnung der Dinge: Eine Wissens- und Mediengeschichte des Unfalls (Bielefeld: transcript 2009); Gabriele Schabacher, "Staged Wrecks: The Railroad Crash between Infrastructural Lesson and Amusement," in Infrastructuring Publics/Making Infrastructures Public, ed. Matthias Korn et al. (Wiesbaden: Springer VS, 2019), 185-206. 


\section{Waiting}

After having discussed differences as well as similar intuitions of the culturaltechniques approach and infrastructure studies, I would like to illustrate their relation to each other by focusing on the practice of waiting. Waiting is an almost unnoticed practice. This is the case for everyday life, as well as in terms of research. Only recently has waiting become a topic of interest. Primarily, the specific positioning of the subject, the affects waiting produces (such as boredom), and the time structure (delay) it goes with were regarded from philosophical, ethical, or anthropological perspectives. ${ }^{24}$ However, waiting is also a low-threshold way of dealing with things. In this respect, waiting is neither a form of use nor a practice of invention or production. However, waiting does something to things. What this practice is about, and why we generally underestimate this type of handling of things, will be outlined in the following. ${ }^{25}$

The word waiting (in German warten) has two meanings: first, it refers to maintenance and upkeep, and second, it refers to the act of waiting and holding out. The connection between the two forms of waiting that are familiar to us today, temporal waiting and perseverance on the one hand, and procedures of maintenance on the other, is not immediately evident. If we follow the term's etymology in the most comprehensive dictionary of the German language, the Deutsches Wörterbuch by the Grimm brothers, the respective entry on the verb warten unfolds a panorama of relations between directed attention and the practices of guarding, watching, and caring - relations that are still visible in the German noun Wärter ${ }^{26}$ (guard, warder). Only in the second half of the forty-two columns of Grimm's entry on warten, we do find the meaning of warten in sense

24 See Thomas Macho, “Waiting," in Gregor Schneider: 7-8:30 pm 05.31.2007, ed. Staatsoper Unter den Linden (Cologne: König, 2007), 31-39; Harold Schweizer, On Waiting (London and New York: Routledge, 2008); on the communicative relevance of delay, see Jason Farman, Delayed Response: The Art of Waiting from the Ancient to the Instant World (New Haven and London: Yale University Press, 2018).

25 For a more comprehensive analysis of the temporal dimensions of infrastructure with respect to the practices of repair, maintenance, repurposing, and abandonment, see Gabriele Schabacher, "Time and Technology."

26 "Wärter," in Deutsches Wörterbuch, vol. 27, ed. Jacob and Wilhelm Grimm (Leipzig: Hirzel, 1922), col. 2168-2170. Even earlier, in 1801, Johann Christoph Adelung claimed that the noun Wärter refers less often to the temporal dimension of waiting (for example, the gatekeeper at the gate) but primarily addresses the action of taking care for something or somebody; see "Wärter, der,” Johann Christoph Adelung, Grammatisch-kritisches Wörterbuch der Hochdeutschen Mundart, vol. 4 (Leipzig: Breitkopf \& Sohn, 1801), 1391. 
of awaiting something to come. ${ }^{27}$ In English, too, there is the dimension of guarding and care in the now obsolete meaning of the verb to wait in the sense of "to (keep) watch" as well as in the word waiter. ${ }^{28} \mathrm{~A}$ waiter is thus primarily someone who observes carefully, and furthermore a "person who waits on or attends another" (be it as private servant or as employee in hotels and restaurants who waits upon the guests during the meals). ${ }^{29}$ This correlation of keeping watch, care, and service is also central to the German verb (be)wirten, that is, to cater for somebody, which is said to stem from the basic meaning of caring ("pflegen") for somebody or something, making today's meaning of (be)wirten in the sense of providing hospitality only a special case (even though it is the oldest). ${ }^{30}$

Waiting is thus a specific form of care that consists of an attentiveness to things, people, or animals. It can be characterized as a practice that derives its temporality from the objects cared for, that is, from the things, people, and animals that it follows in order to preserve them.

Unlike the practice of repair, which can be said to react to a disruption or at least an irritation and, therefore, to work "retrospectively," the practice of waiting is directed prospectively towards the future of the objects being cared for. In doing so, waiting cultivates a specific type of concern - maintenance - that is directed towards preventing harm by caring for things, animals, and people on a regular basis. These acts of maintenance cover proper nutrition and hygiene measures for people, the dismantling, oiling, and cleaning of machines, or the replacing of wear parts. The lifetime of artefacts (and people) thus coincides with the process of their maintenance. Cost-intensive products such as buses or airplanes or infrastructures, as well as goods under conditions of scarcity such as clothes or furniture, tend to live "forever," if they are cared for properly. In the Global South, we can see such a prolongation of lifetimes of cars or bicycles, for example, that are sorted out in the first-use societies of the Western World. ${ }^{31}$ However, the longevity that maintenance practices produce also indicates the fundamental "fragility" of

27 "Warten," in Deutsches Wörterbuch, vol. 27, col. 2125-2167, here col. 2149ff.

28 “wait, v.1," "waiter, n.," in OED Oxford English Dictionary (Oxford: Oxford University Press, 2019), https://www.oed.com (visited on June 22, 2019).

29 "waiter, n.," in $O E D$.

30 "Wirt," in Deutsches Wörterbuch, vol. 30, col. 629-648, here col. 630. I thank Bernhard Siegert for the hint on the relation between warten and wirten.

31 See Hans P. Hahn, “Das 'zweite Leben' von Mobiltelefonen und Fahrrädern: Temporalität und Nutzungsweisen technischer Objekte in Westafrika," in Kulturen des Reparierens: Dinge Wissen - Praktiken, ed. Stefan Krebs, Gabriele Schabacher, and Heike Weber (Bielefeld: transcript, 2018), 105-119. 
matter. ${ }^{32}$ Therefore, research on repair and maintenance is related to a general shift in perspective towards a "broken world thinking." 33 It allows to see that things do not "exist" in an easy way, but only because of unaccountable acts of work and care invested in them. This is the reason why the notion of care has been discussed recently also in science and technology studies. ${ }^{34}$

Nevertheless, in the context of infrastructures, maintenance work displays certain characteristics that adapt the general feature of care to what are generally considered modern conditions. As outlined above, the premodern care for things and people has a cyclic structure. Care work in this sense is repeated work that takes place on a more or less regular basis. The industrialization and urbanization of the nineteenth century bring about ideas of linear progress and permanent acceleration. ${ }^{35}$ This also affects the cyclic structure of care, in that the maintenance of things is secularized and becomes itself scheduled according to industrial time regimes.

Two aspects should be noted here. First, the idea of so-called life cycle management, that is, the attempt to extensively exploit all the phases during the life of a product. ${ }^{36}$ This can go along with planned obsolescence, as implanted limits for household and for consumer products (and the respective fashion cycles) allow for the exact calculation of the artefacts' life times. This illustrates that "maintainability" 37 is not the main priority when it comes to the capitalist logic of value creation. Second, maintenance processes themselves are organized according to specific regimes of timing that structure their execution, repetition, and control. Procedures such as customer services for household appliances, regular inspection for vehicles, as well as health check-ups and computer updates establish the repetition of certain maintenance activities according to specific intervals, and thus obey modern time regimes of logistics and management.

32 Jérôme Denis and David Pontille, "Material Ordering and the Care of Things," Science, Technology, \& Human Values 40, 3 (2015): 338-367, here 341.

33 Jackson, “Rethinking Repair,” 221.

34 See Maria Puig de la Bellacasa, "Matters of Care in Technoscience: Assembling Neglected Things," Social Studies of Science 41, 1 (2011): 85-106; Annemarie Mol et al. (eds.), Care in Practice: On Tinkering in Clinics, Homes and Farms (Bielefeld: transcript 2010); Denis and Pontille, "Material Ordering."

35 See Hartmut Rosa, Beschleunigung: Die Veränderung der Zeitstrukturen in der Moderne (Frankfurt am Main: Suhrkamp, 2005).

36 See John Stark, “Product Lifecycle Management," in Product Lifecycle Management (Volume 1): 21st Century Paradigm for Product Realisation, ed. Stark (London et al.: Springer, 2015, third edition), $1-29$.

37 Denis and Pontille, "Material Ordering," 358. 


\section{The Maintenance of Steam Engines}

For the adaptation of care practices to industrial settings, the history of the Technischer Überwachungsverein (TÜV) provides a good example. ${ }^{38}$ Just as infrastructural improvements in the nineteenth century took place on the basis of a successful "learning" from accidents, ${ }^{39}$ industrially supported maintenance activities also followed from disastrous failures of machines and infrastructures. In the nineteenth century, the most salient technical failure concerned the steam engine, or more precisely: accidents by exploding boilers. Therefore, the revision of boilers was a central task of supervision and inspection. ${ }^{40}$ After another of these fatal accidents in a Mannheim brewery in 1865, twenty regional boiler operators founded the first inspection association for steam boilers in 1866, which later became part of the steam boiler inspection associations DÜV (Dampfkessel-Überwachungs- und Revisionsvereine). The accident prevention of these privately organized inspection associations was so successful that they were granted broader competences during the 1880s, which made them in turn politically influential, as all factories were affected by regulations of boiler inspection. Important questions that arose in connection with this reorganization of the entire steam boiler inspection business ("Dampfkesselrevisionswesen") ${ }^{41}$ were inspection intervals and resulting costs, as the private associations prescribed boiler inspections more often than the state. Whereas the private associations demanded external inspections at least once a year, and internal inspections every two years, the state allowed longer intervals of two years for external inspections and even six years for internal inspections. ${ }^{42}$

In nineteenth-century publications on the topic of maintenance, the upkeep of steam engines is a prominent and recurring theme. Around 1850, explicit

38 See Günther Wiesenack, Wesen und Geschichte der Technischen Überwachungsvereine (Cologne: Heymann, 1971).

39 For this argument see Schabacher, "Staged Wrecks."

40 See Wolfgang Ayaß (ed.): Quellensammlung zur Geschichte der deutschen Sozialpolitik, I. Abteilung: Von der Reichsgründungszeit bis zur Kaiserlichen Sozialbotschaft (1867-1881), vol. 3: Arbeiterschutz (Stuttgart: Fischer, 1996); W.A. (ed.): Quellensammlung zur Geschichte der deutschen Sozialpolitik, II. Abteilung: Von der kaiserlichen Sozialbotschaft bis zu den Februarerlassen Wilhelms II (1881-1890), vol. 3: Arbeiterschutz (Darmstadt: Wissenschaftliche Buchgesellschaft, 1998).

41 "Report on the founding meeting of the central association of the Prussian associations of steam boiler revision," No. 41, June 21 (1884), Zeitschrift des Vereins Deutscher Ingenieure 25, in Ayaß, Quellensammlung, II. Abteilung, vol. 3, 142-145, here 143.

42 "Memorandum of the chairman of the Steam Boiler Inspection Association in Pommern, Hugo Delbrück, for the Prussian Trade Minister, Otto Fürst von Bismarck,” No. 37 (1884), in Ayaß, Quellensammlung, II. Abteilung, vol. 3, 124-128, here 126. 
guidelines for the "Maschinenwärter" (the person operating and maintaining the machine $)^{43}$ provide preparatory remarks on the laws of combustion and the characteristics of steam, followed by chapters on how to heat boilers and keep them running as well as on their components and possible accidents. ${ }^{44}$ The main aspects which should be kept in mind by the "Maschinenwärter" in order to maintain the functioning of the steam engine are listed A to $\mathrm{Z}$. They underline the attention directed to the boiler and the necessity to select the right time for the respective actions: inspecting the water level several times a day, removing the ash if necessary, cleaning the boiler at the right times, observing and regulating the heat of the water, listening to the sound of the steam, lubricating the piston every hour, oiling the bearings at least every day etc.$^{45}$ The list is also given as a supplement in larger letters so that it can be pinned to the wall..$^{46}$

In his guidelines Der Führer des Maschinisten ("The machinist's guide”) from 1845, Ewald Friedrich Scholl considers the necessary attitude of the machine operator. ${ }^{47}$ In the first part, Scholl addresses the relation of the machinist to his work and claims that besides possessing qualities such as health, strength, and endurance, as well as the ability to read and write and manual skills such as that of a blacksmith, locksmith, or carpenter, the machinist should above all pay special attention to the operation of the machine in order to notice the slightest deviation and error. He thus should display a "never resting care for the good operation of the machine." 48

By the end of the century, the tone of the publications on maintenance work changes towards a more practical mastery of the already known malfunctions of steam engines (see Fig. 1) and their different components. ${ }^{49}$ This development is

43 See "Maschinist," in Meyers Großes Konversations-Lexikon, vol. 13 (Leipzig and Vienna: Bibliographisches Institut, 1908), 390.

44 See Baumgartner, Anleitung zum Heizen der Dampfkessel und zur Wartung der Dampfmaschine (Vienna: Heubner, 1841).

45 See Baumgartner, Anleitung, 122-125.

46 See Baumgartner, Anleitung, supplement.

47 Ewald Friedrich Scholl, Der Führer des Maschinisten: Anleitung zur Kenntnis, zur Wahl, zum Ankaufe, zur Aufstellung, Wartung, Instanderhaltung und Feuerung der Dampfmaschinen, der Dampfkessel und Getriebe: Ein Hand-und Hülfsbuch für Heizer, Dampfmaschinenwärter, angehende Mechaniker, Fabrikherren und technische Behörden (Braunschweig: Vieweg und Sohn, 1845).

48 Scholl, Der Führer des Maschinisten, 7.

49 See, for example, Hermann Haeder, Die kranke Dampfmaschine und erste Hülfe bei der Betriebsstörung: Praktisches Handbuch für Betrieb und Wartung der Dampfmaschine (Duisburg: Selbstverlag von Hermann Haeder, 1899, second edition). 


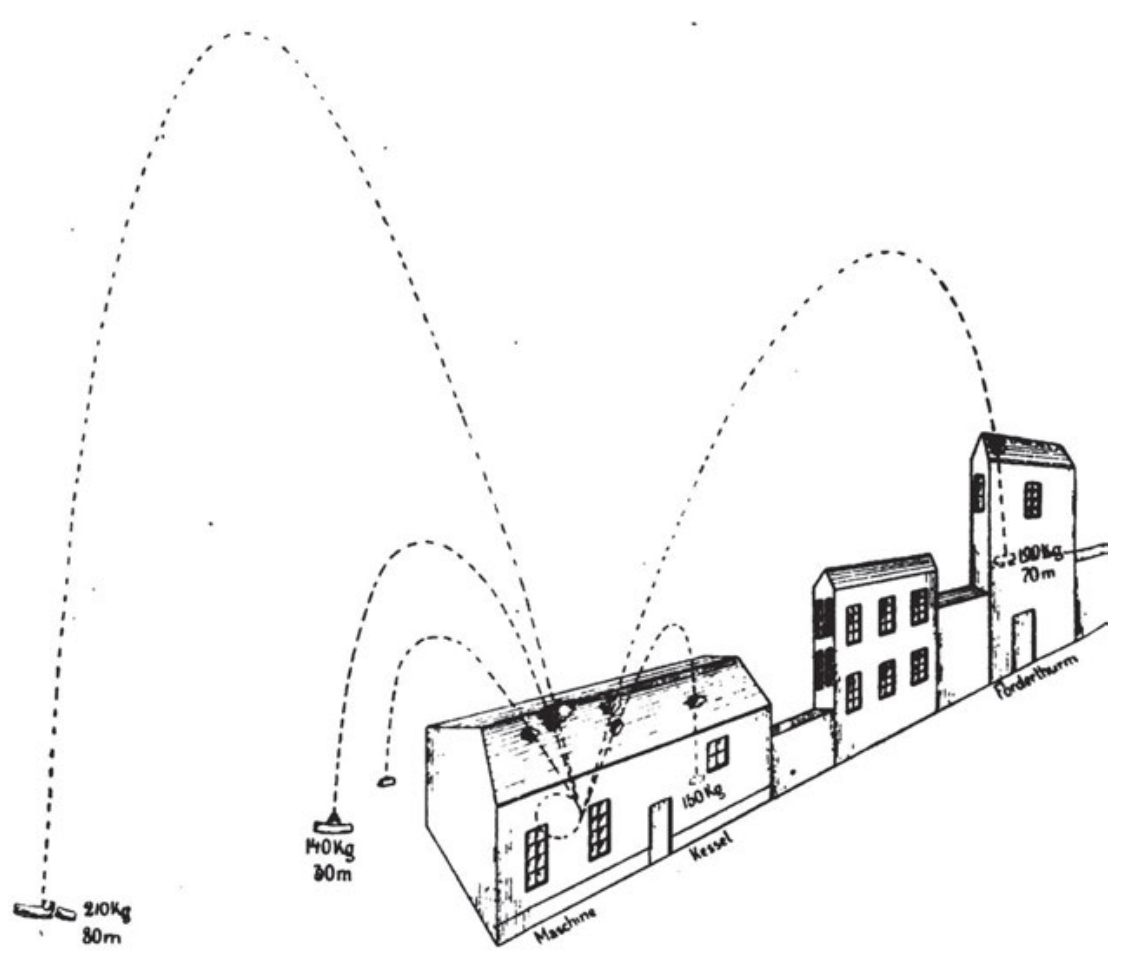

Fig. 620. Situation des Unfalles.

Fig. 1: Sketch of an accident indicating the impact of the explosion of a steam engine's fly-wheel (1899).

part of the establishment of training schools for machinists and other workers in this field. ${ }^{50}$

Questions of maintenance, however, are discussed at this time in relation not only to machines but also to large technical systems such as railway infrastructure. Here again, maintenance costs are an important subject. Interestingly enough, even at the end of the nineteenth century, fixed expenses for maintaining the railway as a whole were difficult to calculate, as there were no reliable data, only different opinions. "Yet I do not remember to have ever seen any attempt to estimate this cost, or to have seen it discussed," Marshall M. Kirkman argues in 1886 with respect to the "cost of maintenance and operating under normal conditions. ${ }^{51}$ For this purpose, Kirkman discusses the deterioration of rails, ties,

50 See “Maschinenwärterschulen,” in Meyers Großes Konversations-Lexikon, vol. 13, 390. 51 Marshall M. Kirkman, Maintenance of Railways (Chicago: Trivess, 1886), 21. 
roadways, bridges, and so on due to climatic and other forces in correlation to the resulting costs for their maintenance (see Fig. 2). He argues that the problems in estimating these costs also depend on regionally different environmental settings. ${ }^{52}$

\section{FIXED EXPENSES.}

Percentage of the total cost of Operating that is due to Maintenance of Organization or that arises from Natural Decay of the property.

\begin{tabular}{|c|c|}
\hline NAME OF ACCOCNT. & $\begin{array}{l}\text { PERCENTAGe. } \\
\text { (Fixed Charge.) }\end{array}$ \\
\hline 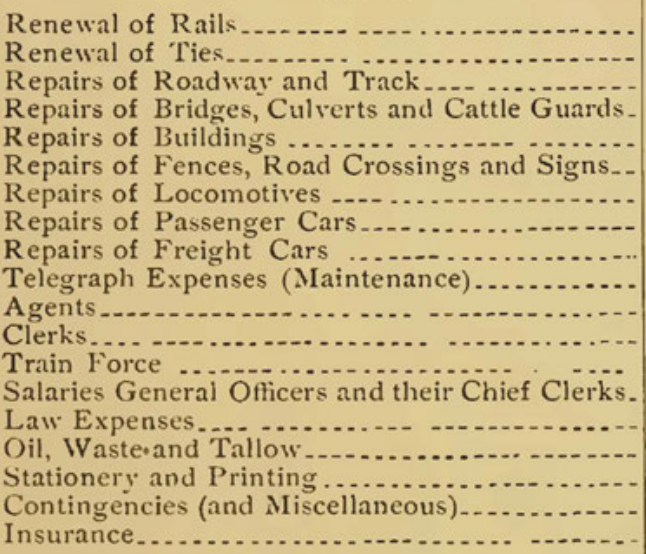 & 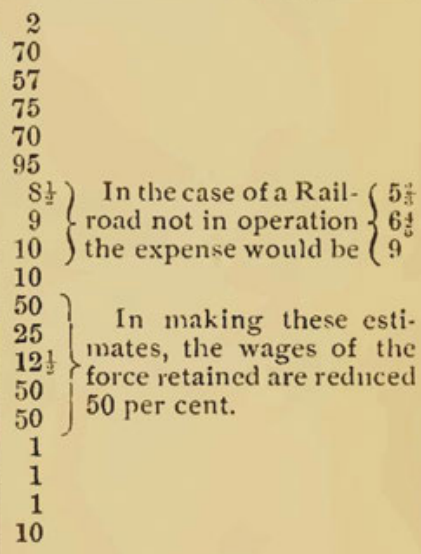 \\
\hline
\end{tabular}

Fig. 2: Railway maintenance costs (1886).

In the German context, railway maintenance ("Bahnerhaltung") becomes prominent during the 1890s. Karl Hartmann, for example, discusses the disadvantages of the existing maintenance procedures that rely on gangs of workmen carrying out corrections wherever necessary, which makes them work in many places without an overall plan. He criticizes the limited reliability of such groups of workers, the lack of overview, the unfair distribution of responsibilities, and unnecessary additional costs. ${ }^{53}$ In his opinion, one should adapt to the procedure

52 See Kirkman, Maintenance, 55.

53 Karl Hartmann, "Bahnerhaltung durch Haupt-Untersuchungen,” Organ für die Fortschritte des Eisenbahnwesens (1892): 147-153, here 148f. 
already in operation in France, where the gangs of workmen are situated near the respective section of the railway they are responsible for:

Each section is paced off once a day. For this purpose, a workman is living at each end, whereas the others live near the middle section. The daily work of the two workers living at the end of the section begins with pacing off and examining the railway; if the worker meets the group, he reports to the foreman and joins the group. ${ }^{54}$

The most important suggestion concerns the introduction of regular general inspections. Hartmann distinguishes two types of causes that affect the state of the railway: regular effects and contingent effects. Whereas the contingent causes have to be removed immediately by "local repairs," the second type of change is brought about by regularly occurring weather conditions and normal operation and can only be detected by the new general inspections. They guarantee a close examination of the railway, in which respective damages are marked with chalk. ${ }^{55}$ With his suggestion to introduce general inspections, Hartmann puts into practice an insight he already formulated in 1837: "the progression of damages can only be prevented by never interrupting the work of repair." 56

As we can see from these examples, the discourse concerning the maintenance of steam engines in the mid-nineteenth century takes up notions of skill and care and underlines the necessity to be attentive to machines. At the end of the century, publications still refer to the skill of machinists and the type of labor they perform, but the focus now is not only on the guidance of the single worker but on the practical training of future machinists as a group. These texts therefore describe procedures of coping with malfunctions that are classified according to different categories, with the fixed expenses caused by maintenance and repair as well as the organization of regular inspection businesses (such as the DÜV in Germany). The question thus is no longer whether maintenance is important, but how to organize it. The focus shifts from the reliability of the single worker to the reliability of the inspection procedure. In this development, we find evidence for

54 Hartmann, "Bahnerhaltung," 150; my translation. See also "Bahnwärter," in Enzyklopädie des Eisenbahnwesens, vol. 1, ed. Victor von Röll (Berlin and Vienna: Urban \& Scharzenberg 1912, second completely revised edition), 460-463.

55 Hartmann, "Bahnerhaltung," 151.

56 Karl Hartmann, Praktisches Handbuch über die Anlage von Eisenbahnen, ihre Kosten, Unterhaltung und ihren Ertrag, über die Anfertigung und Prüfung guß- und stabeiserner Schienen, und die Einrichtung der Dampf- und anderen Eisenbahnwagen (Augsburg: Jenisch und Stage, 1837), 352; my translation. 
the influence of management ideas and bureaucratic organization brought about by the process of industrialization and especially the railroad. ${ }^{57}$

\section{Conclusion}

Practices of maintenance concerning devices, machines and large technical systems are in fact closely linked to basic processes within the realm of the organic: cultura in the sense of the Latin verb colere means to care for the soil in agriculture, which is fundamental for the growth and prosperity of life - plants, animals, and humans (think of the concept of education as letting a seed flourish). Maintenance in the sense of waiting is thus related to a specific temporality that demands that one waits (sometimes holds out), but always that one watches and lets things take their own time.

The notion of waiting thus points to the temporal dimension of cultural techniques, on the one hand, and infrastructures, on the other. As an agricultural, premodern practice, waiting implies a cyclic understanding of time, in which the act of waiting follows the time of the things it preserves. With industrialization and ideas of acceleration, progress, and optimization, the time of care in the sense of repair and maintenance gets industrialized, too. The natural rhythms and cycles of care become secularized as planned maintenance and repair intervals within the management of a product's life cycle.

In terms of the connection between cultural techniques and infrastructures, the activity of waiting (in the wider sense) is thus an example for a set of extremely underestimated practices of concern that are relevant to the continuity of culture, society, and technology. The relevance of these cultural techniques of care can only become visible, however, if they are not exclusively analyzed in relation to the present and in differentiated settings such as the hospital or the repair workshop. Rather, their historical development and premodern bias has to be taken into account, allowing one to locate the waiting of people and the waiting of things in one and the same field. In doing so, it is possible to show how cultural techniques of care (for things, people, etc.) represent indispensable practices within the framework of infrastructural systems, without which these could not exist and "survive."

57 See James R. Beniger, The Control Revolution: Technological and Economic Origins of the Information Society (Cambridge, MA, and London: Harvard University Press, 1986); JoAnne Yates, Control through Communication: The Rise of System in American Management (Baltimore: Johns Hopkins University Press, 1989). 